\title{
The Significance of Pharaonic Royal Names in Graeco-Roman Temples
}

\section{Haitham Taher Abd El Hafeez}

Lecturer, Tourist guidance department, Higher Institute for tourism and hotels (EGOTH) - Luxor

\begin{abstract}
Some Pharaonic royal names could be attested in the Graeco-Roman temple inscriptions. The names of Khufu, Pepi I, Amenemhet I, and Tuthmosis III are found within the inscriptions of Dendera temple. The Ancient Egyptian royal names in Dendera refer to the buildings activities of those monarchs in the area, or a mention of some activities of the main festivals during the time of those kings. In Esna temple the name of Tuthmosis III is referred to, showing that the festival of Hathor is performed according to the way it was done during the time of this king. The Inscriptions of Edfu temple refer to two monarchs of the $12^{\text {th }}$ dynasty, namely Amenemhet I and Senwsert I, who had special relation to the temple, and during their time the festivals of the temple were performed. The names of Darius I, Darius II, Nectanebo I, and Nectanebo II, were mentioned in the texts of Edfu temple, for they made donations to the temple during their time.
\end{abstract}

Keywords: Pharaonic royal names, Graeco-Roman temples, Dendera, Esna, Edfu.

\section{Introduction}

Within the texts of the Graeco-Roman temples some Pharaonic royal names could be attested. The names of the Ancient Egyptian kings who had special relations to those temples are found within the texts. Some Ancient Egyptian royal names could be gathered from the texts of Dendera, Esna, and Edfu temple, to show the relation of those monarchs to certain places.

The majority of the Ancient royal names is mentioned within the texts of the temple festival calendars, referring to the antiquity of those festivals, and tries to date them to the Ancient time. The majority of the names are found in the temple of Dendera, other names are attested in Esna and Edfu temples.

\section{Dendera}

The name of the area of Dendera as Iwnt is mentioned in the Pyramid texts, the area is linked to the history of some monarchs from the Old Kingdom like Snefru, Khufu, and king Pepi I who offered a golden statuette of Ihy to Hathor, passing to Amenemhet I and Sensusert I, to Tuthmosis III and Ramesses III, till the GraecoRoman period $^{(1)}$. The names of some pharaohs are attested on the walls of the temple specially those who have certain building activities in the temple of Hathor. Pepy I name is linked with that of Hathor of Dendera; there is evidence upon the walls of the temple of Dendera to show that Pepy I, even in Ptolemaic times, was honored locally as one of the most memorable of the kings who contributed to Hathor cult in this city $^{(2)}$.

The most striking part of this evidence consists of three scenes of similar composition, showing a king kneeling before Hathor and presenting the figure of a child upon his outstretched hands ${ }^{(3)}$. Two identical scenes are found in room XX, on eastern and western wall showing Pepi I kneeling with statue of Ihy before Hathor with shrine above (pl. 1 and 2) ${ }^{(4)}$. Hathor here is labeled: nbw "Hathor, mistress of the house of the shrine, height four cubits, (of) gold" and she stands before a shrine of the type pictured in the inscription. No inscription is given for the king rather than his name $(\square / 4)$ (5).

The third scene in crypt no. $4^{(6)}$ represents a statue group of Pepi I kneeling with statuette of Ihy before four figures of Hathor; Hekenemankh, Pepy, and three Hathors (plate 3). Pepi addresses four gold statues of Hathor. Above him is written:

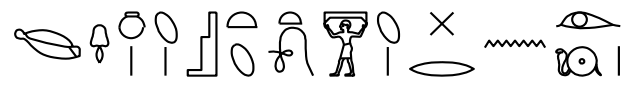


Iwa mnx n sA Ast twA pt sA wr n irt Ra

"Excellent heir to the son of Isis, who raises the Great son to the Eye of $\operatorname{Re}^{\text {(7) }}$.

The small figure he presents is:

A single column before the two reads:

DN $\$ 100000$

ms n sA.T Xr mnit sSSt

"I have brought thy son bearing menit and sistrum "(9).

Another evidence of Pepy I's importance in Dendera is to be found among the inscriptions of crypt no. 9. A long text referring to gods of Dendera, names of the temple and of Hathor and her feasts, building restoration of Tuthmosis III, and discovery of original plan in wall of Pepi $\mathrm{I}^{(10)}$. The text tells that:

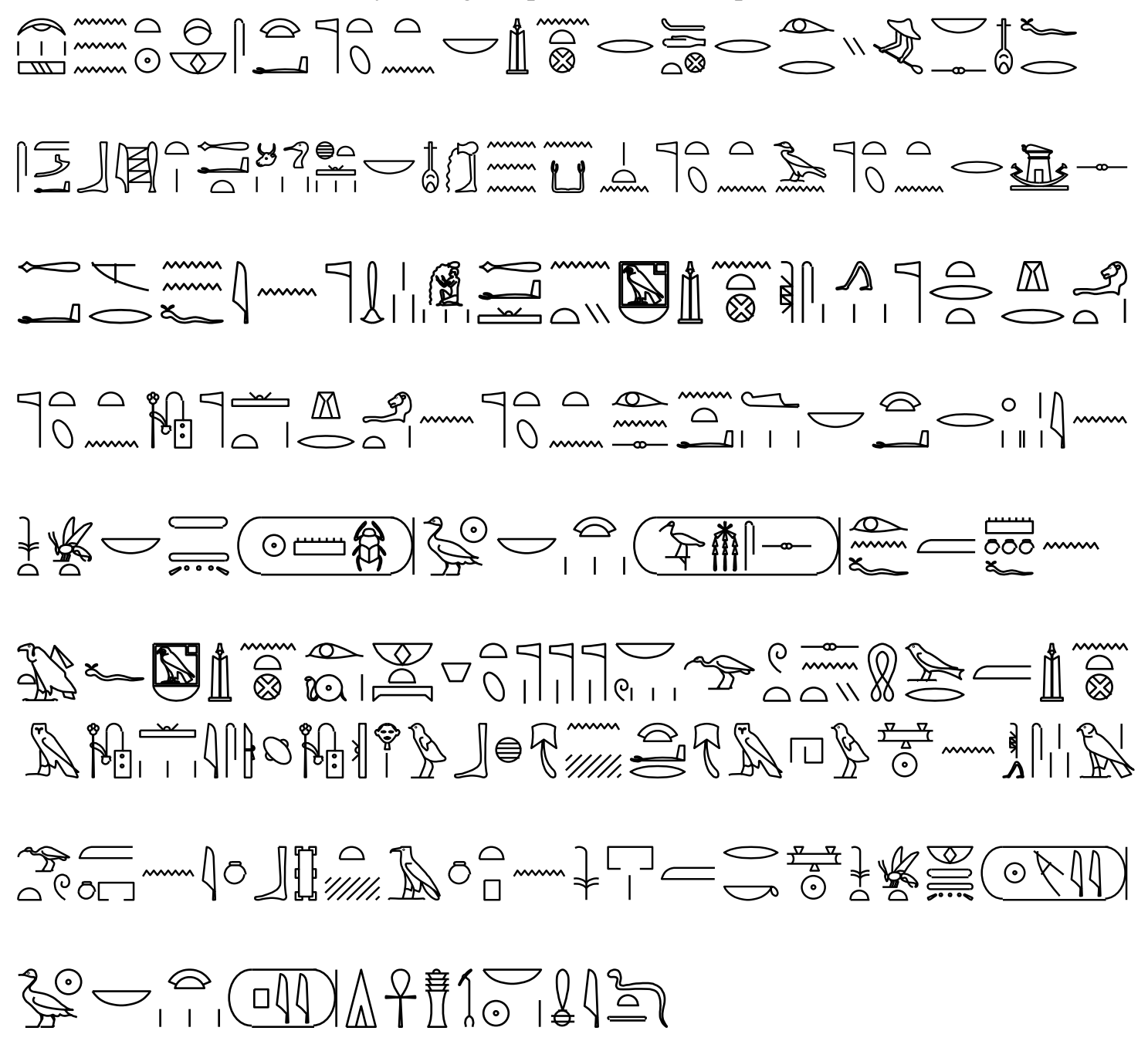

Abd 3 Smw, psDntyw, sxa ntrt tn, nbt Iwnt $r$ BHdt, $r$ irt Xnt.s nfrt. \%mAa aAbt aAt iHw Apdw, ixt nbt nfrt wabt $n$ kA n ntrt tn, aq n ntrt tn r wiA.s, aA-mrwt rn.f in Hmw-ntr wabw aAw nw @t-Hr nbt Iwnt, Smswt ntrywt Xr-HAt ntrt tn sS ntr-mDAt Xr-HAt $n$ ntrt tn irt n.s nt-a xaw r hrw 4 in nsw-biti, nb tAwy (Mn-xprRa), sA-Ra, nb xaw (+Hwty-ms) ir.n.f m mnw.f n mwt.f @t-Hr nbt Iwnt, Irt-Ra nbt pt, Hnwt ntrw nbw. Gm.tw snT wr n Iwnt m sSw isw, sS Hr wbx n xar m hAw n Smsw-@r gm.tw m-Xnw Inb m ATp n pr-nw m rk nsw-biti, nb tAwy (Mry-Ra) sA Ra, nb xaw (Ppi) di anx, Dd, wAs mi Ra Dt.

"Third month of summer, new moon feast, Transference of this goddess, the mistress of Dendera (in procession) to Edfu to make her goodly journey ; bringing of great offerings, cattle and fowl, and all things goodly and pure to the kA of this goddess, when this goddess has entered her bark whose name is ari 
$\operatorname{mr}(\mathrm{w} . \mathrm{t})$ - (all this) by the prophets and the great wab-priests of Hathor, Mistress of Dendera, the attendants of the goddess who are(?) before this goddess, the scribe of sacred writings who is( ?) before this goddess. Performing for her all customary observances of (?) the procession for four days. It is the King of Upper and Lower Egypt, Lord of the Two Lands, Mn-Xpr-Ra, Son of Re, Lord of Diadems, Tuthmosis who made it as his monument for his mother, Hathor, Mistress of Dendera, Eye of Re, mistress of all the gods. The great plan in (of ?) Dendera was found as (in?) ancient writings which were written upon a leather roll in the period of the Followers of Horus; (it) was found in Memphis(?) in a coffer(?) of the king's house in the time of the King of Upper and Lower Egypt, Lord of the Two Lands, Mry-Ra, Son of Re, Lord of Diadems, $\mathrm{Pe}(\mathrm{p}) \mathrm{y}$, given all life, stability and dominion like Re forever." ${ }^{(11)}$.

A similar text is the heading on the north-end wall. The text mentions the names of the temple and its parts and priests, and nome standard, with text below concerning restoration of work of Khufu by Thutmosis III ${ }^{(12)}$. The text reads:

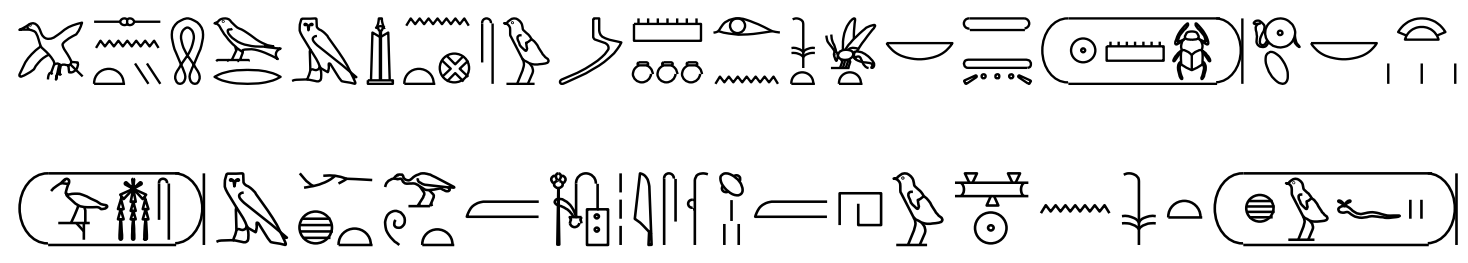

PA snT wr m Iwnt smAw mnw iry n nswt-biti, nb tAwy (Mn-xpr-Ra) sA Ra, nb xaw (+Hwty-ms) m xt gm.tw $\mathrm{m}$ sSw isw m hAw n nswt (\#wfw)

"The great plan in (of) Dendera, the renewal of monuments which the king of Upper and Lower Egypt, Lord of the Two Lands, Mn-xpr-Ra, Son of Re, Lord of the Diadems, Tuthmosis made, after (it) was found in ancient writings in the time of king Khufu ${ }^{(13) "}$

Those two texts are trying to prove a link between Dendera and The kings Tuthmosis III, Khufu, and especially Pepi I, who is clearly appears in the scenes of the temple. A reference to Ancient Egyptian royal name in the ceiling of the eastern staircase is a sandstone block from a statue with a name of Amenemhat ${ }^{(14)}$, text reads:

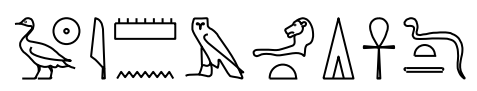

sA Ra Imn-m-HAt di anx Dt

The son of Re Amenemhat, given life forever"

This king could be Amenemhat I, for a Granite lintel of Amenemhat I found in debris of Hypostyle ${ }^{(15)}$. Amenemhet I must had some building activities in the temple ${ }^{16)}$.

\section{Esna}

Esna appears to have been functioned as a cult center at least as early as the eighteenth dynasty, which would explain why, perhaps, Thutmosis III continues to be commemorated on the walls of Esna temple ${ }^{(17)}$.

The southern part of the festival calendar, on the inner side of the front wall ${ }^{(18)}$ mentions Tuthmosis III reads:

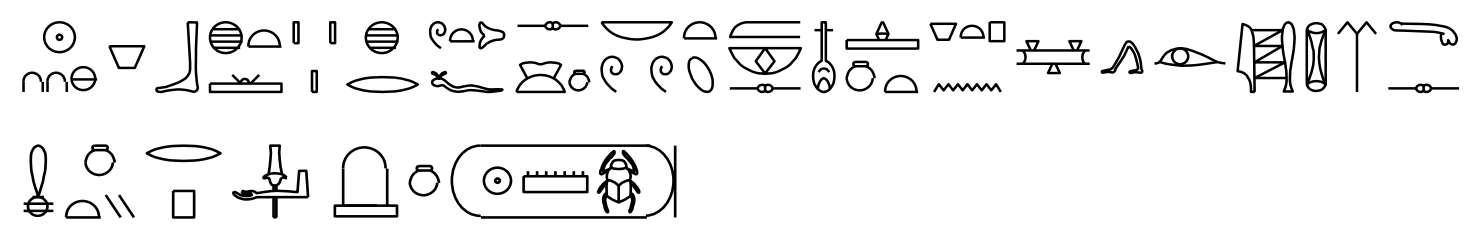

sw 29 abA ixtw xr.tw.f sxa Nbtww m Hb.s nfr Htp.m tA wsxt n Smyt iri aAbt m-bAH.s mi nty r pA aHaw n (Mn-xpr-Ra)

"The $29^{\text {th }}$ day of the 3rd month of the Inundation: They call it: "The presentation of offerings". Making the procession of Nebetu in her good feast: coming back into outer hypostyle, presenting offerings to her: in accordance with the specification on the stela of $\mathrm{Mn}-\mathrm{xpr}^{-\mathrm{Ra}^{(19)}}$. 
The well-known festival calendar of Esna, prescribes that, at the end of the festivity occurring on the 29th day of the second month of the inundation season, offerings should be given to the goddess Nebetu "according to that which is written on the stela of Thutmoses III." This indicates that a temple and a cult had existed in Esna at or since the time of Thutmoses III $^{(20)}$. The same calendar text is found on column $14^{(21)}$, and ads aHaw pA aA n (Mn-xpr-Ra) (+Hwty-ms)"great stela of Menkheperre Thutmosis.

\section{Edfu}

The history of Edfu goes back to the Old Kingdom period, many blocks of earlier history were found in the site of the Graeco-Roman temple ${ }^{(22)}$. In the temple inscriptions names of two monarchs of the Middle kingdom are noted.

The festival calendar of Hathor on the north-west doorway of forecourt, mentions the names of two Middle kingdom pharaohs ${ }^{(23)}$. The text reads:

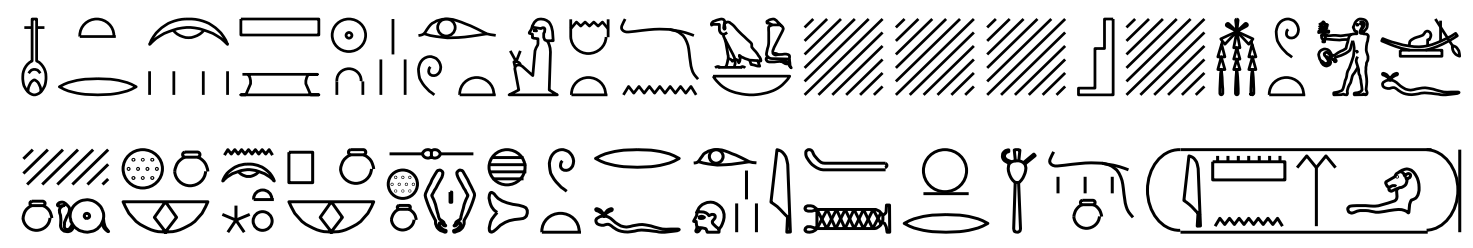

Nfr Abd 4 Smw sw 13 ir.tw Hmt mDwt nbt [rxyt] ..........Ast...mswt IHy psDntyw n Abd pn Hb sxn xr.tw r.f ir(t) tp.w AH r wDwt n (Imn-m-HAt)

\section{Day 12 Shmu 4:}

Feast of the new moon, of this month: it is also called "feast of reunion". They celebrate the rite of first-fruit of the fields, in accordance with the decree of (king) Amenemhat. ${ }^{(24)}$.

The king name Amenemhat which is mentioned refers to the Middle kingdom history of the temple and the area. Evidence for Middle Kingdom settlement remains have been discovered along the eastern side of Tell Edfu, close to the Ptolemaic temple enclosure wall. Here a large administrative building complex has been excavated, which seems to have functioned as the residence of the local mayor here ${ }^{(25)}$

Another part of the text reads:

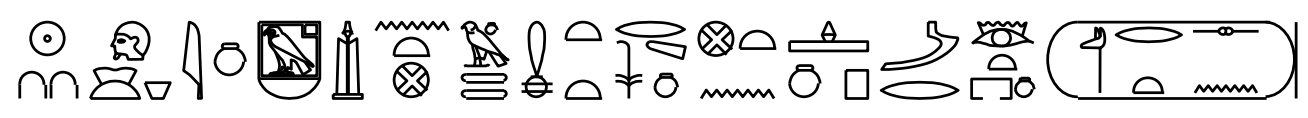

sw 27 xa in@t-Hr nbt Iwnt @r-smA-tAwy mitt r rsyt n niwt Htp n pA mArw n (\%-n-Wsrt)

Day 27:

Going out in procession by Hathor, Lady of Dendera, and Harsomtus likewise, to the south of the town/domain. Stopping [at] the Maru-chapel of king Senwsert ${ }^{(26)}$.

The solar god Horus of Edfu-Behdet had a Maru, or viewing place ${ }^{(27)}$, to the south-east of his Ptolemaic temple, and local texts mention that there had been a Maru at this place from the early times of King Menibre (Thirteenth Dynasty). There was another Maru of Horus at Edfu-Djeba. At Dendera Horus Behdty had also a Maru, thought to originate from the reign of Senwsert ${ }^{(28)}$.

A long text on the eastern outer wall mentions the donations to the temple by Darius I, Darius II, Nectanebo I, and Nectanebo II $^{(29)}$. The text listing the offerings and donations for the gods of Edfu, The text mentions that those donations:

AB:

Iw Hnk r hn r HAt sp . n (_riwS)

(Offerings) that were donated up to [.] Year of reign of (Darius I. $)^{(30)}$

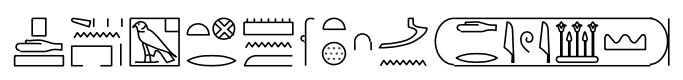


pA tAS n pr @t-Hr r mn m HAt sp 19 nt (_riwS)

The nome of Pathyris, up to the 19th year (Darius II.) $)^{(31)}$

紊

\section{I wHm.w n Hnk n HAt sp 1 nt (Nxt-nb.f)}

Which were confirmed by the Foundation from year 1 of the (Nectanebo I) ${ }^{(32)}$

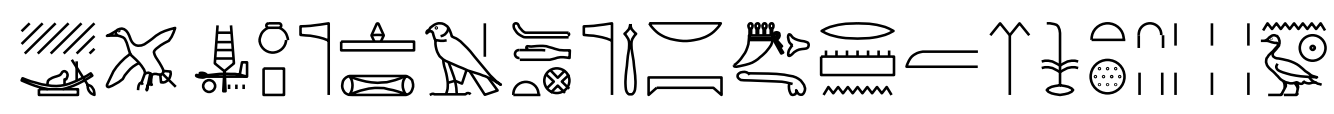

\section{(खण丁口)}

Im pA aHa n pA Htp ntr @r-BHdty ntr aA nb pt Dr bAH r mn m HAt sp 18 nt sA Ra (nxt-@r-Hbyt)

The ownership of the temple lands of Horus Behedeti, the great God, the Lord of heaven, from the beginning until the 18th year of the reign of the son of Re (Nectanebo II.) ${ }^{(33)}$ This refers to the antiquity of those donations, and tries to link the history of the temple to those monarchs.

\section{Conclusion}

Some Pharaonic royal names are attested in Graeco-Roman temples in Dendera, Esna, and Edfu. In the temple of Dendera there are three scenes represent Pepi I, and his name is mentioned three times in the temple inscriptions, this refers to the importance of Pepi I in Dendera, where the texts consider him the main founder of the temple. Also Thutmosis III and Khufu are mentioned within Dendera inscriptions, both of Thutmosis III and Khufu are mentioned two times, where the texts try to link them to the temple history. A reused block from the time of Amenemhat $I$ is found in the western staircase ceiling, this king also had certain activities in Dendera.

In Esna temple inscriptions, the name of Thutmosis III is mentioned two times in the calendar texts. The texts try to date one of the city festivals to the time of this king. In Edfu temple, also in the festival calendar of Hathor on the north-west doorway of the forecourt, the text dates the event to the time of a king called Amenemhat. The procession is passing mArw chapel dates to the time of a king called Senwsert. A long text on the eastern outer wall mentions the donations to the temple from the time of Darius I, Darius II, Nectanebo I, and Nectanebo II.

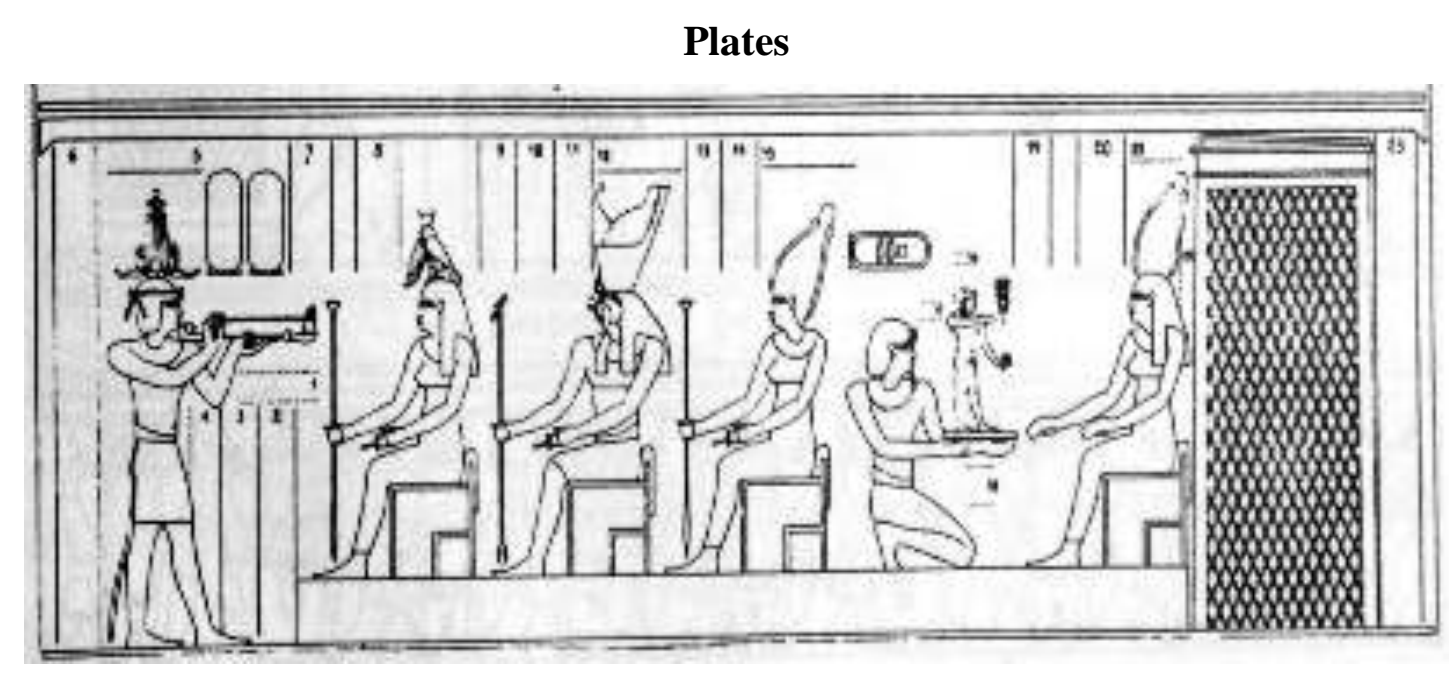

Plate (1) Pepi I kneeling with statue of Ihy before Hathor with shrine above (Chassinat, Dendera, III, pl. 180) 


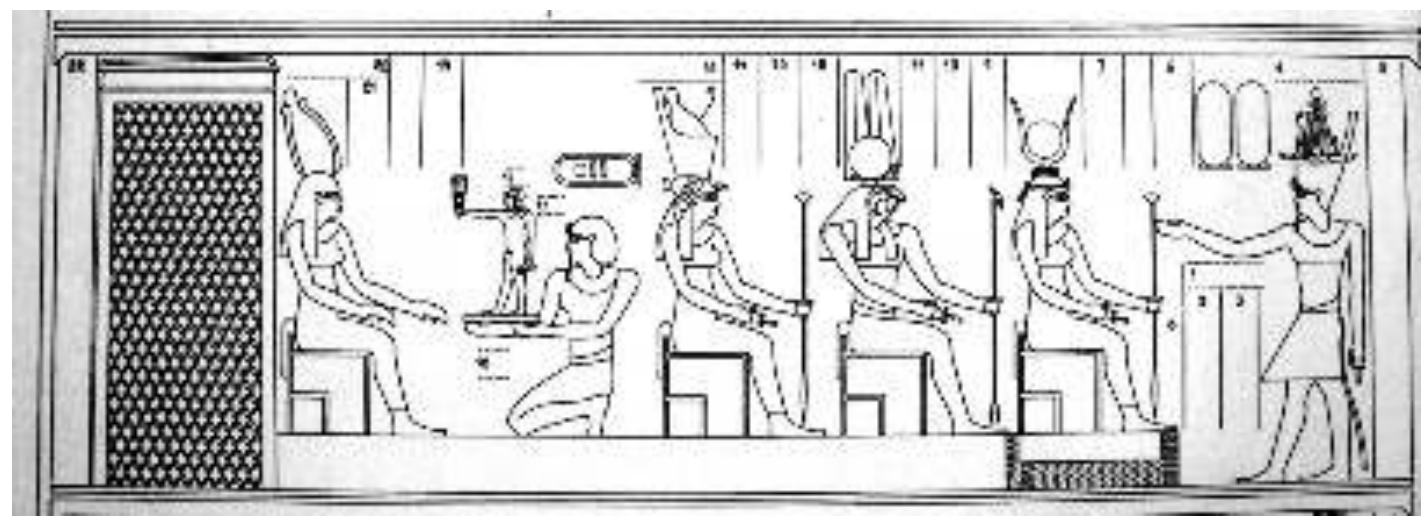

Plate (2) Pepi I kneeling with statue of Ihy before Hathor with shrine above (Chassinat, Dendera, III, pl. 190)

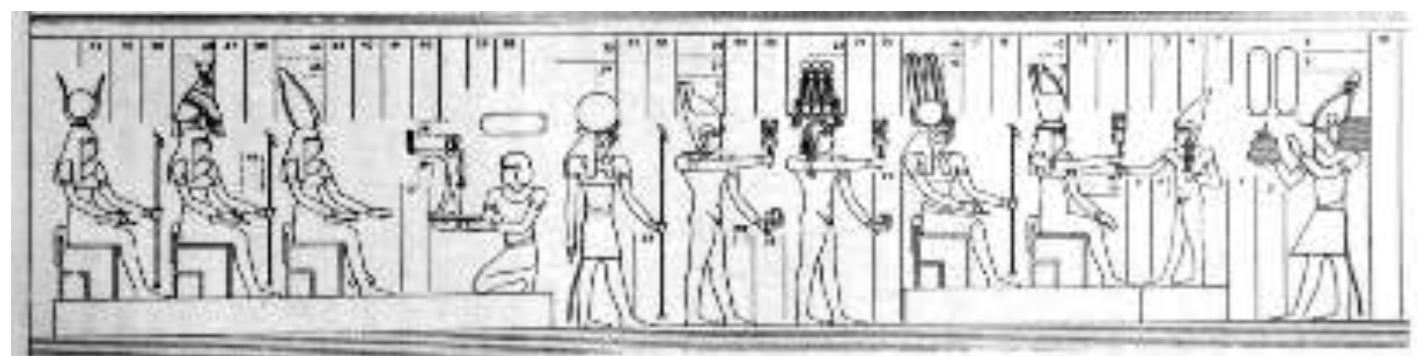

Plate (3) statue group of Pepi I kneeling with statuette of Ihy presented to three Hathors (Chassinat, Dendera, V, pl. 446)

\section{Notes}

*The author like to thank Maged Mahgoub for his help in this research, especially in Graeco-Roman texts.

${ }^{1}$ For the history of Dendera see Daumas, F., Dendera in LA, I col 1060-1061; Montet, P.(1961) Géographie de l'Egypte Ancienne, Paris, II, 86.

${ }^{2}$ Fischer, H. G., (1968) Dendera in the third millennium B.C. down to the Theban domination of Upper Egypt, New York. The texts were collected in: Daumas, F., (1953) Le trône d'une statuette de Pepi Ier trouve a Dendera, BIFAO 52 p. 163-172.

${ }^{3}$ Fischer, Dendera, p.40.

${ }^{4} \mathrm{PM}$ Room XX (PM VI, 71), scene on eastern wall PM scene (198), room J of Chassinat ;Chassinat E., (1935) Le temple de Dendera, iii, pl.180, 189, pp.72-3), scene on the western wall PM scene (199) (Chassinat, Dendera, iii, pl.190, 197 pp.84-5)

${ }^{5}$ Fischer, Dendera, p.42.

${ }^{6}$ PM VI p.87, scenes (83)-(84); Chassinat, Dendera, V, pl. 443, 446, 448 pp.159-160.

${ }^{7}$ Fischer, Dendera, p.42.

${ }^{8}$ Fischer, Dendera, p.42.

${ }^{9}$ Fischer, Dendera, p.42.

${ }^{10}$ PM VI, 90, scene 129.

${ }^{11}$ Fischer, Dendera, p.44; Cauville S.,(2004) Dendera V-VI traduction, Les crypts du temple d'Hathor vol.1, OLA 131, p.461-462.

${ }^{12}$ PM VI, 90; scene 127.

${ }^{13}$ Fischer, Dendera, p.47; Cauville, Dendera , 480-481.

${ }^{14} \mathrm{PM}$ VI, 91.

${ }^{15} \mathrm{PM}$ VI, 110. 


\footnotetext{
${ }^{16}$ Daumas, Dendera, col. 1061.

${ }^{17}$ Bianchi, R. S., (2001) Esna in Redford, D. B., The Oxford Encyclopedia of Ancient Egypt, Oxford, vol. I, p. 483; Sauneron S., Esna, in $L A$, II, cl. 32.

${ }^{18}$ PM, VI, 113.

${ }^{19}$ For this translation see: El Sabban, Sh., (2000) Temple festival calendars, Liverpool, 161-161; Sauneron, S., (1963) Le temple d'Esna II, IFAO, 126; Sauneron, S., (1962) Esna, V, Les fêtes religieuses d'Esna aux derniers siècles du paganisme, 42.

${ }^{20}$ Hallof, J., (2011), Esna. In Willeke Wendrich (ed.), UCLA Encyclopedia of Egyptology, Los Angeles. Available at :

http://digital2.library.ucla.edu/viewItem.do?ark=21198/zz002b2xv3 (October 2011)

${ }^{21}$ PM, VI, 112.

${ }^{22}$ Vernus P., Tell Edfu, in $L A$, VI, col.324.

${ }^{23}$ PM, VI, scene (52) p.127; Chassinant E., (1930) Edfou, V ,IFAO, 356,1. 8-357, 1. 1.

${ }^{24}$ El Sabban, Temple festival Calendars, 177.

${ }^{25}$ Moeller, Nadine, 2013, Edfu. In Willeke Wendrich (ed.), UCLA Encyclopedia of Egyptology, Los Angeles. Available at : http://digital2.library.ucla.edu/viewItem.do?ark=21198/zz002gw1kt

${ }^{26}$ El Sabban, Calendars, 178; Chassinant E., Edfou, V , 357, 1.6-7.

${ }^{27}$ For the meaning of mArw as viewing place see: Badawy, A., (1956) Maru-Aten: Pleasure Resort or Temple? JEA 42, pp. 58-64

${ }^{28}$ Badawy, Maru-Aten, pp. 58-64 ; Chassinat, E., (1931) Le mar du roi Menibre, a Edfou, BIFAO 30 p. 229-303; Gauthier $D G$, III, 8.

${ }^{29} \mathrm{PM}, \mathrm{VI}, 164$, scene (337)-(344); Chassinat, Edfu, VII, 189-252; Meeks D., (1972) Le grand texte des donations au temple d'Edfou, Bde 59, Le Caire, 19-52, 134-135.

${ }^{30}$ Chassinat, Edfu, VII, 219, 1.7; Meeks, Donation, 52.

${ }^{31}$ Chassinat, Edfu, VII, 248, 1. 3-4; Meeks, Donation, 20.

${ }^{32}$ Chassinat, Edfu, VII, 248, 1. 11-12; Meeks, Donation, 21.

${ }^{33}$ Chassinat, Edfu, VII, 247, 1. 14; Meeks, Donation, 19.
} 